part II. New York: Marcel Dekker, 1981 :ch 13. (Lung biology in health and disease. Series. Vol 17.)

${ }^{5}$ Robin ED, O'Neill RP. The fighter versus the non-fighter. Control of ventilation in chronic obstructive lung disease. Arch Environ Health $1963 ; 72: 125-7$

${ }^{6}$ Rosser R, Guz A. Psychological approaches to breathlessness and its treatment. $\mathcal{F}$ Psychosom Res 1981 ;25:439-47.

${ }^{7}$ Anonymous. Centrally acting drugs in chronic airways obstruction. $\mathrm{Br}$ Med f 1980;281:1232-3.

${ }^{8}$ Anonymous. Diazepam and breathlessness. Lancet 1981 ;ii:242-3.

${ }^{9}$ Jones NL. Pulmonary gas exchange during exercise in patients with chronic airway obstruction. Clin Sci 1966;31:39-50.

${ }^{10}$ Matthews AW. The relationship between central carbon dioxide sensitivity and clinical features in patients with chronic airways obstruction. $Q \mathcal{Y}$ Med 1977;46:179-95.

${ }^{11}$ Cotes JE. Lung function: assessment and application in medicine. 3rd ed. Oxford: Blackwell Scientific, 1975.

12 Spiro SG, Dowdeswell IRG. Arterialised earlobe blood samples for blood gas tensions, $B r \mathcal{F}$ Dis Chest $1976 ; 70 \cdot 263-8$.

${ }^{13}$ McGavin CR, Artvinli M, Naoe H, McHardy GJR. Dyspnoea, disability, and distance walked: comparison of estimates of exercise performance in respiratory disease. $\mathrm{Br} M e d \mathcal{F} 1978 ;$ ii :241-3.

14 Butland RJA, Pang JA, Gross ER, Woodcock AA, Geddes DM. Two-, six-, and twelve-minute walking tests in respiratory disease. $\mathrm{Br} \mathrm{Med} \mathcal{F}$ $1982 ; 284: 1607-8$.

15 Woodcock AA, Gross ER, Gellert A, Shah S, Geddes DM. Breathlessness and exercise tolerance in subjects with airways obstruction and normal blood gases: the effects of dihydrocodeine, alcohol and caffeine. $N$ Engl f Med $1981 ; 305: 1611-6$.

16 Woodcock AA, Gross ER, Geddes DM. Oxygen relieves breathlessness in pink puffers. Lancet $1981 ; \mathrm{i}: 907-9$.

17 Woodcock AA. MD thesis. Breathlessness in man: measurement and modification. University of Manchester, 1982.

${ }^{18}$ Burrows B, Niden AH, Fletcher CM, Jones N. Clinical types of chronic obstructive lung disease in London and in Chicago. Am Rev Resp Dis $1964 ; 90: 14-27$.

${ }^{19}$ Fletcher CM, Jones NL, Burrows B, Niden AH. American emphysema and British bronchitis. Am Rev Resp Dis 1964;90:1-13.

${ }^{20}$ Marcus JH, McLean RL, Duffell GM, Ingram RH. Exercise performance in relation to the pathophysiologic type of chronic obstructive pulmonary disease. Am 7 Med 1970;49:14-21.

21 Filley GF, Beckwitt BJ, Reeves JT, Mitchell RS. Chronic obstructive bronchopulmonary disease: II oxygen transport in two clinical types. Am $\mathcal{F}$ Med 1968;44:26-37.

22 Morgan AD, Peek DF, Buchanan D, McHardy GJR. Psychological factors and beliefs affecting exercise tolerance in chronic bronchitis. Clin Sci 1982;63:40P.

${ }^{23}$ Adams L, Chronos N, Guz A. The dyspnogenic effect of hypoxiadissociation from ventilatory response. Clin $S c i$ 1982;63:17P.

24 Guz A, Adams L, Minty K, Murphy K. Breathlessness and the ventilatory drives of exercise, hypercapnia and hypoxia. Clin $S c i$ 1981;60:17p-18p.

\title{
Vitamin D state of Asians living in Pakistan
}

\author{
A RASHID, T MOHAMMED, W P STEPHENS, S WARRINGTON, J L BERRY, E B MAWER
}

\begin{abstract}
Asians living in Pakistan have serum 25-hydroxycholecalciferol concentrations which are well within the normal range and significantly higher than in Asians resident in Britain. Clearly, Asians can maintain an adequate vitamin $D$ state given an abundant supply of ultraviolet light, and the expression of vitamin $D$ deficiency is an environmental and not a genetically determined characteristic.

The risk of an Asian developing vitamin $D$ deficiency increases after migration to Britain. The most efficient way to treat this is by supplementation with vitamin $D$.
\end{abstract}

\section{Introduction}

Asian immigrants to the United Kingdom are known to be at risk of developing osteomalacia or rickets. ${ }^{1}$ The numbers developing clinical bone disease are relatively small, ${ }^{2}$ but between $33 \%$ and $44 \%$ of Asian immigrants have biochemical evidence of vitamin $\mathrm{D}$ deficiency with low serum concentrations of 25 -hydroxycholecalciferol ${ }^{3}(25(\mathrm{OH}) \mathrm{D})$. The aetiology of the

Crumpsall Hospital, Manchester

A RASHID, $\mathrm{MB}, \mathrm{CHB}$, house physician

Manchester Royal Infirmary, Manchester M13 9WL

T MOHAMMED, MB, CHB, house physician

W P STEPHENS, MD, MRCP, senior registrar in medicine

Birch Hill Hospital, Rochdale, Lancashire

S WARRINGTON, BSC, district dietitian

University of Manchester, Manchester M13 9PL

J L BERRY, PHD, research fellow

E B MAWER, PHD, senior research fellow condition remains controversial and various environmental and genetic factors have been implicated. Inadequate habitual solar exposure, dietary practices, skin colour, and an entirely speculative "metabolic defect" have all been suggested. Despite this controversy there is very little information on the biochemical vitamin $\mathrm{D}$ state of Asians living in their home country, and such information might provide a valuable insight into the factors causing the low serum $25(\mathrm{OH}) \mathrm{D}$ concentrations among immigrants to Britain.

We have compared the vitamin D state of Pakistanis residing in Rochdale, Lancashire (latitude $53^{\circ} 26^{\prime} \mathrm{N}$ ), with that of a group of Pakistanis residing in the Punjab (roughly $29^{\circ} \mathrm{N}$ ).

\section{Subjects and methods}

Of the 262 Asians seen in a large survey of Rochdale Asians," 90 hailed from the Lahore and Rawalpindi area of Pakistan. These subjects were interviewed by AR and TM and contact addresses of relatives in Pakistan obtained. During a subsequent visit to Pakistan in the summer of 1981 attempts were made to trace these relatives and to solicit their help with the study. In the event, 92 indigenous Pakistanis ( 48 male, 44 female) were investigated. Nineteen of these were first-degree relatives of immigrants to Britain, and the remaining 73 were recruited from among the neighbours of relatives declining to take part in the study. The median age of these subjects was 29 years. There was one 11 -year-old, and the remainder ranged from 14 to 75 years. They were considered to be highly representative of the community from which the Asian immigrants to Britain had originated. Of the 92 subjects, 31 were villagers and 61 were city dwellers.

All participants in the study underwent venesection, and the frozen serum was returned to Manchester for measurement of the serum $25(\mathrm{OH}) \mathrm{D}$ concentration by competitive protein-binding assay. ${ }^{2}$ Clinical evidence of vitamin $D$ deficiency was sought by questioning and by examination, and a dietary history was taken by the seven-day recall method to ascertain the dietary intake of vitamin D. 
In order to compare the biochemical profile of indigenous Pakistanis with that of migrants to Britain, 92 subjects identically matched for age and sex were selected from the group of Asians originally seen in Rochdale in the spring of 1980 and who are described in full elsewhere. ${ }^{2}$ Forty-eight of these were male and 44 female, and their median age was 29 years (range 11-60). Since $25(\mathrm{OH}) \mathrm{D}$ concentrations fluctuate with season, however, it is not entirely valid to compare the summer $25(\mathrm{OH}) \mathrm{D}$ concentrations in Pakistan with the spring 25(OH)D concentrations in Rochdale. The serum 25(OH)D concentrations of indigenous Pakistanis were therefore also compared with those in 61 unmatched Rochdale Asians sampled in the Autumn of 1980 . These comprised 25 male and 36 female subjects with a median age of 31 years (range 8-58).

Results are expressed either as mean \pm 1 SD or as the median and range. Statistical analysis was by standard parametric and non-parametric tests. The food tables of McCance and Widdowson ${ }^{4}$ were expanded by adding certain Asian recipes ${ }^{5}$ and traditional local dishes-for example, goat curry, buffalo milk-to help in the dietary evaluation.

\section{Results}

No subject seen in Pakistan had clinical evidence of vitamin D deficiency. The figure shows that the serum $25(\mathrm{OH}) \mathrm{D}$ concentrations in indigenous Pakistanis (median $74 \mathrm{nmol} / \mathrm{l}$, range $7.5-157.5 \mathrm{nmol} / \mathrm{l}$;

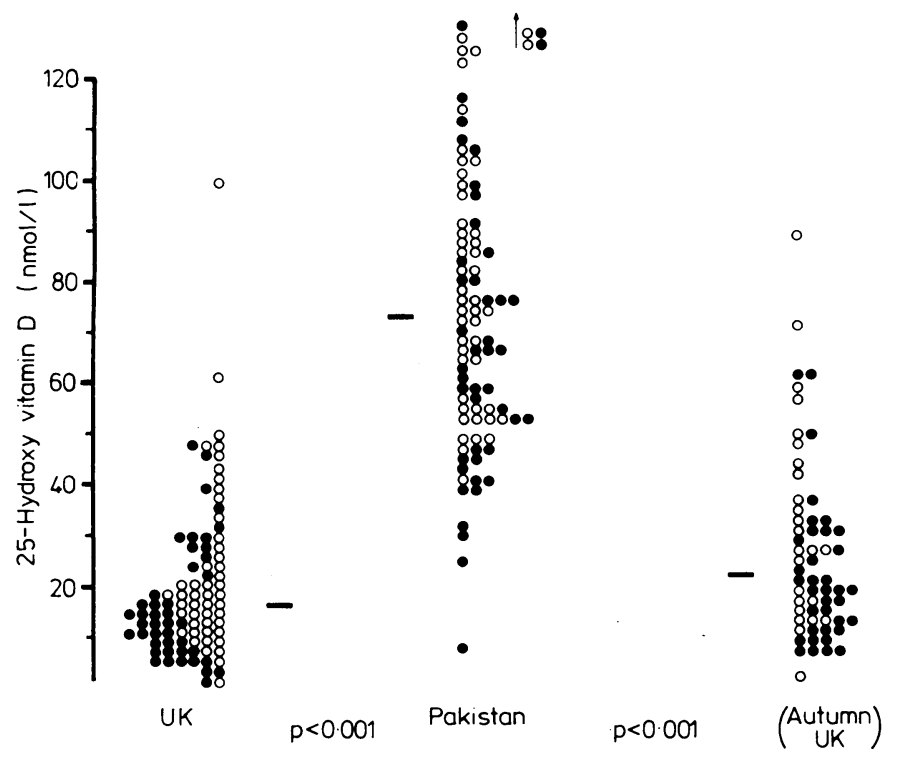

Serum 25-hydroxy vitamin D concentrations in group of Asians resident in Britain and group of age-matched and sex-matched Asians resident in Pakistan. For comparison, serum 25-hydroxy vitamin $D$ concentrations shown for group of unmatched immigrant Asians sampled in autumn. Bars are median values. $O=$ Males. $O=$ Females.

Conversion: $S I$ to traditional units-25-Hydroxy vitamin $\mathrm{D}: 1 \mathrm{nmol} / 1 \approx$ $0.4 \mathrm{ng} / \mathrm{ml}$.

$29 \cdot 7 \mathrm{ng} / \mathrm{ml}, 3 \cdot 0-63 \cdot 1 \mathrm{ng} / \mathrm{ml}$ ) were significantly higher than in both age-matched and sex-matched migrant Asians in Britain sampled in the spring (median $16.5 \mathrm{nmol} / 1$, range $1.5-100.0 \mathrm{nmol} / 1 ; 6.6 \mathrm{ng} / \mathrm{ml}$, $<1.0-40.0 \mathrm{ng} / \mathrm{ml})(\mathrm{p}<0.001)$ and in unmatched migrant Asians sampled in the autumn (median $23 \mathrm{nmol} / 1$, range $1.5-82.0 \mathrm{nmol} / 1 ; 9.2 \mathrm{ng} / \mathrm{ml}$, $0.6-33.0 \mathrm{ng} / \mathrm{ml})(\mathrm{p}<0.001)$. Only one indigenous Pakistani had an abnormally low concentration $(7.5 \mathrm{nmol} / \mathrm{l} ; 3.0 \mathrm{ng} / \mathrm{ml})$. She was a 24-year-old city dweller noted for strict observance of purdah and who described her occupation as "housework." Indigenous Pakistani women had lower serum $25(\mathrm{OH}) \mathrm{D}$ concentrations $(67 \cdot 3 \pm 28.3 \mathrm{nmol} / 1$; $27 \cdot 0 \pm 11.3 \mathrm{ng} / \mathrm{ml})$ than the men $(82.3 \pm 27.5 \mathrm{nmol} / 1 ; 33.0 \pm 11.0 \mathrm{ng} /$ $\mathrm{ml})(\mathrm{p}<0.02)$. There was no significant difference in $25(\mathrm{OH}) \mathrm{D}$ concentrations between villagers and city dwellers.

The mean dietary intake of vitamin $D$ was estimated as $1.05 \pm$ $0.80 \mu \mathrm{g} /$ day in Pakistan and $2.67 \pm 2.00 \mu \mathrm{g} /$ day in Britain. The form of the diet was essentially the same in the two countries.

\section{Discussion}

It is clear from the results of the serum $25(\mathrm{OH})$ D estimations that the vitamin D state of the indigenous Pakistani population is generally excellent. This indicates that Asians, if given adequate solar exposure, can maintain high/normal serum $25(\mathrm{OH}) \mathrm{D}$ concentrations despite a very small dietary intake of vitamin $\mathrm{D}$ and the consumption of a wheat-based diet whose nature is considered by some investigators to be conducive to rickets. ${ }^{6}$ The implication is that Pakistanis enter Britain in a vitamin $\mathrm{D}$ replete state, which is consistent with the finding of normal serum 25(OH)D concentrations in East African Asians on arrival in this country ${ }^{7}$ and with the gradual fall in serum $25(\mathrm{OH}) \mathrm{D}$ concentrations seen during the first two years of domicile in Britain. ${ }^{8}$ Studies examining the comparative serum calcium, phosphorus, and alkaline phosphatase values between migrant and indigenous Asians also show that the vitamin D state in the latter group is superior. ${ }^{910}$ Furthermore, our results support the view that vitamin $D$ deficiency among Asians in Britain is an expression of the environmental change consequent on migration and is not an intrinsic characteristic of Indian races.

The principal source of vitamin $D$ is ultraviolet light, and several factors may be implicated in the causation of the lower $25(\mathrm{OH}) \mathrm{D}$ concentrations seen in migrant Asians. The move to a more northerly latitude will restrict the availability of ultraviolet light, ${ }^{11}$ as will the greater cloud cover and air pollution in Britain. ${ }^{12}$ The screening effect of pigmented skin may be more important when the supply of ultraviolet light is attenuated, ${ }^{13}$ and the effects of a move from a hot to a cold climate should not be underestimated, since there is less incentive to go out in the sun in Britain. ${ }^{14}$

It is frequently stated that the Asian preference for a secluded life style and the female obligation to cover the skin adequately on leaving the house contributes to their low serum $25(\mathrm{OH}) \mathrm{D}$ concentrations, and there is some biochemical evidence to support this claim. ${ }^{15}$ Our finding of lower 25(OH)D concentrations among indigenous Pakistani women compared with the men presumably reflects the widespread observance of purdah, but the intense source of solar ultraviolet light available in Pakistan nevertheless is enough to maintain normal 25(OH)D concentrations in most of the women. On migration to a country with a restricted availability of ultraviolet light Asians do not change their cultural practices in a way which compensates for this disadvantage, and the ambient $25(\mathrm{OH}) \mathrm{D}$ concentrations are consequently lower than in their home country. Osteomalacia and rickets do occur in India under certain environmental conditions, ${ }^{1}$ but our results suggest that this does not indicate a suboptimal vitamin $\mathrm{D}$ state in the population as a whole.

It is debatable whether exhortations to the Asian community to increase their exposure to the sun will prove an effective prophylactic measure against vitamin $\mathrm{D}$ deficiency. Disappointing results of such a policy have been obtained in Rochdale, ${ }^{2}$ and there are moral objections to a campaign which actively encourages changes in the cultural practices of migrants which are related to deeply held religious beliefs. Cultural change may hold the key to the long-term reduction of this environmental problem, but perhaps we should allow "natural adaption" to take place without enticement. In our opinion, the only way to guarantee a rapid improvement in the vitamin D state of the Asian community is to provide extra vitamin $D$. The most efficient way is by supplementation. ${ }^{316}$

We thank Professor $S \mathbb{W}$ Stanbury for constant support and encouragement and Dr M Palmer for statistical help. AR and TM were helped by travelling scholarships from the British Medical Students Trust, and TM was supported by an award from the British Nutrition Foundation. Further financial help was provided by the Central Manchester Research Grants Committee and by a programme grant from the Medical Research Council to Professor Stanbury. 
${ }^{1}$ DHSS. Rickets and osteomalacia. Rep Health Soc Subj (Lond) 1980; No 19.

${ }^{2}$ Stephens WP, Klimiuk PS, Warrington S, Taylor JL, Berry JL, Mawer EB. Observations on the natural history of vitamin $\mathrm{D}$ deficiency among Asian immigrants. $Q \mathcal{F}$ Med 1982;51:171-88.

${ }^{3}$ Dunnigan MG, McIntosh WB, Sutherland GR, et al. Policy for prevention of Asian rickets in Britain: a preliminary assessment of the Glasgow rickets campaign. $\mathrm{Br} \mathrm{Med} \mathcal{f} 1981 ; 282: 357-60$.

4 Paul AA, Southgate DAT. McCance and Widdowson's the composition of foods. London: HMSO, 1978. (MRC Special Report Series, No 297.)

${ }^{5}$ Stephens WP, Klimiuk PS, Warrington S, Taylor JL. Observations on the dietary practices of Asians in the United Kingdom. Human Nutrition: Applied Nutrition (in press).

${ }^{6}$ Dunnigan MG. Asian rickets and osteomalacia in Britain. In: Child nutrition and its relation to mental and physical development. Kellogg Company of Great Britain, 1977:43-70.

7 Stamp TCB, Walker PG, Perry W, Jenkins MV. Nutritional osteomalacia and late rickets in Greater London, 1974-79. Clin Endocrinol Metab 1980;9:81-105.

${ }^{8}$ Preece MA, Tomlinson S, Ribot CA, et al. Studies of vitamin D deficiency in man. $Q \mathcal{F}$ Med 1975;44:575-89.

9 Hodgkin P, Kay GH, Hine PM, Lumb GA, Stanbury SW. Vitamin D deficiency in Asians at home and in Britain. Lancet 1973; ii:167-71.
${ }^{10}$ Rab SM, Baseer A. Occult osteomalacia amongst healthy and pregnant women in Pakistan. Lancet 1976;ii:1211-3.

11 Johnson FS, Mo T, Green AES. Average latitudinal variation in ultraviolet radiation at the earth's surface. Photochem Photobiol 1976;23: 179-88.

12 Neer R, Clark M, Friedman V, et al. Environmental and nutritional influences on plasma 25 hydroxyvitamin $\mathrm{D}$ concentration and calcium metabolism in man. In: Vitamin D. Biochemical, chemical and clinical aspects related to calcium metabolism. Berlin: Walter De Gruyter, 1977: 595-606.

${ }^{13}$ Clemens TL, Adams JS, Henderson SL, Holick MF. Increased skin pigment reduces the capacity of skin to synthesise vitamin $\mathrm{D}_{3}$. Lancet $1982 ; \mathrm{i}: 74-6$.

${ }^{14}$ Pettifor JM, Ross FP, Solomon L. Seasonal variation in serum 25 hydroxycholecalciferol concentrations in elderly South African patients with fractures of femoral neck. $\mathrm{Br}$ Med F 1978;i:826-7.

15 Stephens WP, Klimiuk PS, Warrington S, Taylor JL, Mawer EB. Seasonal changes in serum 25 hydroxyvitamin D concentrations among Asian immigrants. Clin Sci 1982;63:577-80.

${ }^{16}$ Stephens WP, Klimiuk PS, Berry JL, Mawer EB. Annual high-dose vitamin D prophylaxis in Asian immigrants. Lancet 1981 ;ii:1199-201.

(Accepted 27 October 1982)

\title{
Epidemiology of cholera in travellers, and conclusions for vaccination recommendations
}

\author{
HUGO MORGER, ROBERT STEFFEN, MEINRAD SCHÄR
}

\begin{abstract}
All cases of cholera imported to Europe and North America between 1975 and 1981 were reviewed to assess the danger of cholera for visitors to endemic areas. Data were obtained from the health authorities of the respective countries.

From a total of 129 cases notified to the World Health Organisation detailed reports were obtained on 117 patients. Of these, $66(56 \%)$ were immigrants, .refugees, from endemic areas, or foreign workers returning from leave in their native countries. Only $51(44 \%)$ were citizens of countries in Europe or North America. The incidence per journey for foreign travellers visiting Africa or Asia was about 1 in 500000 . Stay in hospital was always short, and fewer than $2 \%$ of patients died.

In view of the minimal risk and lack of reliability of cholera vaccination, such protection is not indicated for ordinary tourists visiting developing countries.
\end{abstract}

\section{Introduction}

There are vast discrepancies about who should be immunised against cholera. For example, Manson's Tropical Diseases still claims that cholera vaccination "is necessary for travellers to West and East Africa, Egypt, the Sudan, the Near and Middle East, Pakistan, India, Burma and South East Asia."' In contrast,

\footnotetext{
Institute of Social and Preventive Medicine, University of Zurich, CH-8006 Zurich, Switzerland

HUGO MORGER, MD, resident

ROBERT STEFFEN, MD, head, vaccination department

MEINRAD SCHÄR, MD, MPH, professor
}

the US Department of Health and Human Services recommends such immunisation only if an international certificate of vaccination against cholera is required as a condition for entry, or for "special high-risk groups that work and live in highly endemic areas under less than adequate sanitary conditions and those persons with compromised gastric defense mechanisms." 2 The World Health Organisation does not expressly state that any traveller should have this vaccination. ${ }^{3}$ To clarify this disparity we have analysed all cases of cholera imported to Europe and North America (Canada and the United States) in the period $1975-81$.

\section{Methods}

The health authorities of all industrialised countries in Europe and North America who notified the WHO of imported cases of cholera were asked in each case to fill in a questionnaire covering both personal data (age, sex, nationality, country of residence, destination, purpose and duration of the journey, and previous vaccination) and specific information about the cholera (presumed place of infection, clinical course). Only those cases that were confirmed microbiologically and were imported after infection abroad are included here. Only the health authorities of Spain and Yugoslavia failed to reply.

\section{Results}

Between 1975 and 1981, 129 cases imported to European countries or to North America were detected. Of the 117 patients on whom complete data were available $51(44 \%)$ were citizens of industrial nations. Of these, 34 went to the endemic area for a holiday, six for a visit, and seven for professional reasons; in the remaining four the purpose of the journey was unknown. Thirty per cent of this partial population stayed in the endemic region for less than a week, and $88 \%$ for up to one month. Foreign workers living in industrial countries who returned after a home leave in their native countries accounted for 44 patients (38\%), while 22 persons $(19 \%)$ were immigrants, refugees, or tourists from endemic areas. 